\title{
PENGARUH KEPEMIMPINAN GURU TERHADAP MOTIVASI BELAJAR PESERTA DIDIK DI SMP NEGERI 5 ENREKANG
}

\author{
KASMAWATI \\ Fakultas Tarbiyah dan Keguruan UIN Alauddin Makassar \\ Jl. HM. Yasin Limpo No. 36 Makassar \\ Email: kasmawati6131@gmail.com
}

\begin{abstract}
:
This study aims to Know the leadership of teachers in SMP Negeri 5 Enrekang, to determine the motivation of learners in SMP Negeri 5 Enrekang, to know the leadership of teachers to motivation learners in SMP Negeri 5 Enrekang. The type of research is quantitative. The population in this study were all students in SMP Negeri 5 Enrekang which amounted to 280 people. The sampling technique used is Random Sampling. The instruments used are teacher leadership and scale of learning motivation. Processing techniques and data analysis using descriptive statistical analysis and inferential statistics. Based on the technique of descriptive statistical data analysis, teacher leadership in SMP Negeri 5 Enrekang is in the medium category, and the motivation to study in SMP Negeri 5 Enrekang also in the medium category. Based on the technique of analyzing inferential statistic data obtained $p$ value $=0.000$ ( $p<0.005)$. This means that there is influence of teacher leadership to motivation learners learn in SMP Negeri 5 Enrekang.
\end{abstract}

Keywords: Teacher Teaching, Learning Motivation.

\section{PENDAHULUAN}

endidikan merupakan salah satu upaya untuk membangun dan meningkatkan mutu sumber daya manusia menuju era globalisasi yang penuh dengan tantangan sehingga disadari bahwa pendidikan merupakan sesuatau yang sangat fundamental bagi setiap individu. Oleh karena itu, kegiatan pendidikan tidak dapat diabaikan begitu saja, terutama dalam memasuki era persaingan yang semakin ketat, tajam, berat pada abad milenium ini (Rivai dan Murni, 2012: 1).

Hal ini sejalan dengan Undang-Undang Republik Indonesia Nomor 20 Tahun 2003 tentang sistem pendidikan nasional yang menjelaskan bahwa:

Pendidikan adalah usaha sadar dan terencana untuk mewujudkan suasana belajar dan proses pembelajaran agar peserta didik secara aktif mengembangkan potensi dirinya untuk memiliki kekuatan spiritual keagamaan, pengendalian diri, kepribadian, kecerdasan, akhlak mulia, serta keterampilan yang diperlukan dirinya, masyarakat, bangsa dan negara (Undang-Undang RI No. 20 Tahun 2003: 2).

Untuk mencapai tujuan pendidikan yang diinginkan, hal tersebut harus didukung oleh komponen-komponen pendidikan seperti pendidik, peserta didik, kelengkapan alat pendidikan serta sistem pendidikan yang efektif. 
Dalam Al-Qur'an dijelaskan dalam QS. Al -Mujadilah/58: 11 yaitu:

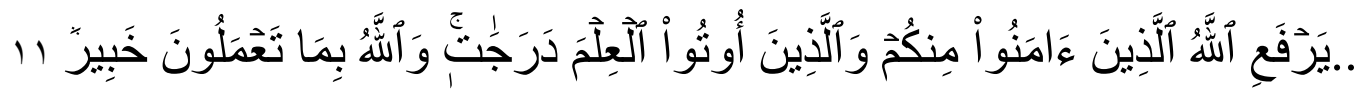

Terjemahnya:

“....Allah akan meninggikan orang-orang beriman diantaramu dan orang-orang yang diberi ilmu pengetahuan beberapa derajat. Dan Allah Maha Mengetahui apa yang kamu lakukan."

Ayat di atas menerangkan bahwa manusia yang berilmu mendapat kedudukan yang lebih tinggi di mata Allah maupun sesama umat manusia. pendidikan yang baik akan menjadi identitas dari kemajuan suatu bangsa. Oleh karena itu, pendidikan menjadi salah prioritas utama dalam pembangunan suatu bangsa. Sesuai dengan Undang-Undang Republik Indonesia Nomor 20 Tahun 2003 tentang sistem pendidikan nasional sebagaimana tercantum pada BAB II pasal 3 memuat dasar, fungsi dan tujuan pendidikan nasional dinyatakan bahwa:

"Pendidikan nasional berfungsi mengembangkan kemampuan dan membentuk watak serta peradaban bangsa yang bermartabat dalam rangka mencerdaskan kehidupan bangsa, bertujuan untuk berkembangnya potensi peserta didik agar menjadi manusia yang beriman dan bertakwa kepada Tuhan Yang Maha Esa, berakhlak mulia, sehat, berilmu, cakap, kreatif, mandiri, dan menjadi warga negara yang demokratis serta bertanggung jawab (Undang-Undang RI No. 20 Tahun 2003: 4)".

Guru menjadi pelaku utama dan penentu berhasil atau tidaknya proses pembelajaran di sekolah. Gurulah yang merancang dan memilih materi, sumber belajar dan media pembelajaran. Guru merupakan pigur utama juga menjadi model atau contoh dan teladan bagi peserta didiknya. Olehnya itu seorang guru harus memiliki pengetahuan pengalaman, keterampilan dan kompetensi mengenai karakter serta memiliki karakter mulia dalam dirinya sendiri yang menjadi bagian dari hidupnya, karena apa yang dilakukannya dengan baik menjadi baik pula pengaruhnya terhadap peserta didik. Pendidikan sulit untuk menghasilkan sesuatu yang baik tanpa dimulai oleh guru-gurunya yang baik (Azisah, 2014: 13).

Guru sangat menentukan mutu pendidikan, berhasil tidaknya proses pembelajaran, tercapai tidaknya tujuan pendidikan dan pembelajaran, terorganisasikannya sarana dan prasarana, peserta didik, media, alat dan sumber belajar. Kepemimpinan guru yang baik dapat menciptakan efektifitas dan efesiensi pembelajaran serta dapat membentuk disiplin peserta didik dan guru itu sendiri (Supardi, 2014: 54).

Upaya guru menciptakan suasana pembelajaran yang kondusif peserta didik senantiasa menunjukkan ketekunan, antusiasme, serta penuh partisipasi adalah sesuatu yang sangat urgen dan menentukan keberhasilan pembelajaran. Selain itu ditunjang pula oleh kemampuan guru dalam mencegah timbulnya tingkah laku 
siswa yang mengganggu jalannya kegiatan belajar serta kondisi fisik tempat belajar dan kemampuan guru dalam mengelolahnya (Muzakkir, 2012: 4).

Tinggi rendahnya prestasi belajar ditentukan oleh faktor kepmimpinan guru. Kepemimpinan guru yang baik dapat menorong peserta didik meningkatkan prestasi belajar. Menurut Sondang P. Siagian Kepemimpinan merupakan kemampuan seseorang yang menduduki jabatan sebagai pemimpin untuk memimpin yang terdiri dari mengarahkan, membimbing dan mempengaruhi sesuatu perilaku orang yang dipimpin untuk berfikir dan bertindak seemikian rupa melalui perilaku yang positif guna menapai tujuan. Seorang pemimpin sebaiknya mempunyai kemampuan dalam memimpin yang dapat menunjang terapainya tujuan yang diaharapkan (Siagian, 2000).

Kepemimpinan guru merupakan suatu kemampuan dan kesiapan yang harus dimiliki oleh seorang guru untuk mempengaruhi, membimbing dan mengarahkan atau mengelolah peserta didiknya agar mereka mau berbuat sesuatu demi terapainya tujuan pembelajaran (Supardi, 2014). Sehingga dapat disimpulkan bahwa keberhasilan dalam proses pembelajaran tidak luput dari peran penting kepemimpinan guru. Guru adalah ujung tombak dalam pembelajaran bagi peserta didik. Dikatakan ujung tombak karena dipundak gurulah keberhasilan pembelajaran dipertaruhkan. Dan hanya guru berdedikasi yang mau terbuka terhadap perubahan dan pembaharuan demi keberhasilan peserta didiknya.

Salah satu sekolah adiwiyata yang peduli akan lingkungan yaitu SMP Negeri 5 Enrekang. Berdasarkan pra penelitian di SMP Negeri 5 Enrekang ini ditandai bahwa pemberian motivasi di dalam kelas masih sangat kurang. Hal tersebut ditandai dengan masih kurangnya perhatikan peserta didik dalam kegiatan proses pembelajaran.

Berdasarkan latar belakang di atas, maka rumusan masalah dalam penelitian ini adalah sebagai berikut:

1. Bagaimana kepemimpinan guru di SMP Negeri 5 Enrekang?

2. Bagaimana motivasi belajar di SMP Negeri 5 Enrekang?

3. Apakah terdapat pengaruh kepemimpinan guru terhadap motivasi belajar peserta didik di SMP Negeri 5 Enrekang?

\section{TINJAUAN TEORETIS}

\section{Kepemimpinan Guru}

Faktor kepemimpinan memegang peranan yang penting karena pemimpin itulah yang akan menggerakkan dan mengarahkan organisasi dalam mencapai tujuan dan sekaligus merupakan tugas yang tidak mudah. Menurut George Terry dalam Vaithzal Rivai yang mengemukakan bahwa kepemimpinan adalah kegiatan dalam mempengaruhi orang lain untuk bekerja keras dengan penuh kemauan untuk tujuan kelompok ((Rivai dan Murni, 2012: 285).

Pada intinya pengertian kepemimpinan adalah suatu proses kegiatan 
seseorang untuk menggerakkan orang lain dengan memimpin, membimbing, mempengaruhi orang lain, untuk melakukan sesuatu agar dicapai hasil yang diharapkan (Sutrisno, 2009: 213). Pengertian kepemimpinan guru merupakan suatu kemampuan dan kesiapan yang harus dimiliki oleh seorang guru untuk mempengaruhi, membimbing dan mengarahkan atau mengelola peserta didiknya agar mereka mau membuat sesuatu demi tercapainya tujuan pembelajaran (Muslich, 2007: 8).

Kepemimpinan guru menurut penulis adalah merupakan suatu kegiatan mempengaruhi peserta didik untuk dapat melaksanakan suatu kegiatan pemebalajaran demi tercapainya tujuan pembelajaran yang diinginkan oleh guru atau pendidik. Dalam lingkungan sekolah, guru adalah leader di dalam kelas yang mampu memimpin dan mengarahkan peserta didik untuk mewujudkan suatu tujuan pembelajaran yang efektif dan efesien. $\mathrm{K}$ epemimpinan guru (teacher leadership) mengandung makna bahwa guru bukanlah sabagai seorang sosok individu yang hanya menyampaikan materi selayaknya seorang robot.

\section{Motivasi Belajar}

Motivasi belajar berasal dari kata latin “movere” yang berarti dorongan, daya penggerak atau kekuatan yang menyebabkan suatu tindakan atau perbuatan. Kata "movere" dalam bahasa Inggris, sering disepadankan dengan "motivasion" yang berarti pemberian motif, penimbulan motif, atau hal yang menimbulkan dorongan atau keadaan yang menimbulkan dorongan. Secara harfiah motivasi berarti pemberian motif (Karwati dan Priansa, 2014: 165).

Menurut MC Donald dalam bukunya Abd.Rahim yang mengemukakan bahwa motivasi adalah perubahan energy dalam diri seseorang yang ditandai dengan munculnya feeling dan didahului dengan tanggapan terhadap adanya tujuan (Rahim, 2012: 72).

Motivasi berpangkal dari kata motif yang dapat dirtikan sebagai daya penggerak yang ada di dalam diri seseorang untuk melakukan aktivitas-aktivitas tertentu demi tercapainnya suatu tujuan. Bahkan motif dapat diartikan sebagai satu keadaan yang kompleks dalam diri individu yang mendorong individu untuk berperilaku dalam upaya mencapai suatu tujuan dalam rangka mempertahankan kelangsungan hidup (Surya, 2014: 52). Pengertian motivasi belajar menurut Clayton Alderfer dalam bukunya Nashar motivasi belajar adalah suatu dorongan internal dan eksternal yang menyebabkan seseorang (individu) untuk bertindak atau berbuat untuk mencapai tujuan, sehingga perubahan tingkahlaku pada diri peserta didik diharapkan terjadi (Nashar, 2004: 42).

Motivasi belajar pada hakikatnya merupakan proses yang menunjukkan intensitas peserta didik dalam mencapai arah dan tujuan proses belajar yang dialaminya. Motivasi merupakan keseluruhan daya penggerak di dalam diri peserta didik yang menimbulkan kegiatan belajar, yang menjamin kelangsungan kegiatan 
belajar serta memberikan arah pada kegiatan belajar, sehingga tujuan pembelajaran yang dikehendaki oleh peserta didik dapat tercapai. Motivasi yang menyebabkan peserta didik melakukan kegiatan belajar dapat timbul dari dalam dirinya sendiri maupun dari luar dirinya (Karwati dan Priansa, 2014: 167).

Menurut penulis motivasi belajar adalah keseluruhan kemampuan dalam menggerakan diri seseorang (peserta didik) yang akan mengakibatkan kegiatan belajar dimana menjamin kelangsungan dari kegiatan belajar dan memberikan arah pada kegiatan belajar tersebut, sehingga tujuan yang diinginkan oleh peserta didik bisa tercapai.

\section{METODE PENELITIAN}

Jenis dan Lokasi Penelitian

Jenis penelitian yang digunakan adalah penelitian yang bersifat kuantitatif. Penelitian ini untuk mengetahui bagaimana pengaruh kepemimpinan guru (X) terhadap motivasi belajar peserta didik (Y). Penelitian ini dilaksanakan di SMP Negeri 5 Enrekang Tahun 2016.

\section{Populasi dan Sampel}

Dalam penelitian ini, yang dijadikan populasinya adalah semua peserta didik SMP Negeri 5 Enrekang yang berjumlah 280 peserta didik terdiri dari 89 kelas X, 87 kelas XI, 105 kelas XII (Sumber: staf Tata Usaha SMP Negeri 5 Enrekang, 2016). Sampel dalam penelitian ini yaitu berjumlah 70 peserta didik yang diacak dari 12 kelas.

\section{Metode Pengumpulan Data dan Instrumen Penelitian}

Untuk memperoleh data yang valid dan dapat dipertanggungjawabkan kebenarannya, penelitian ini menggunakan metode angket dan dokumentasi. Instrumen yang digunakan dalam penelitian ini berupa kuesioner (angket) yang disusun dalam bentuk model Skala Likert.

\section{Teknik Pengolahan dan Analisis Data}

Untuk menganalisa data, penulis menggunakan 2 teknik analisis data, yaitu; teknik analisis statistik deskriptif dan teknik analisis statistik inferensial.

\section{HASIL PENELITIAN}

\section{Gambaran Kepemimpinan Guru di SMP Negeri 5 Enrekang}

Berdasarkan hasil penelitian yang telah dilakukan dengan 70 sampel, maka dengan menggunakan angket kepemimpinan guru dapat diperoleh data sebagai berikut: 
Tabel 1.

Statistik Hasil Analisis Kepemimpinan Guru di SMP Negeri 5 Enrekang

\begin{tabular}{|c|c|}
\hline Statistik & Skor Statistik \\
\hline Jumlah Sampel & 70 \\
\hline Nilai Tertinggi & 39 \\
\hline Nilai Terendah & 30 \\
\hline Nilai Rata-Rata & 35,17 \\
\hline Satndar Deviasi & 2,309 \\
\hline
\end{tabular}

Tabel di atas menunjukkan nilai maksimum 39 dan nilai minimum 30 . Sedangkan nilai rata-rata yang diperoleh sebesar 35,17 dan standar deviasi sebesar 2,309. Hasil anlisis deskriptif tersebut akan menggunakan data yang akan digambarkan dalam membuat kategorisasi kepemimpinan guru di sekolah. Adapun hasil kategorisasi dapat dilihat pada table berikut:

Tabel 2.

Distribusi Frekuensi Kategorisasi Kepemimpinan Guru di SMP Negeri 5 Enrekang

\begin{tabular}{|c|c|c|c|c|}
\hline No & Batas kategori & Frekuensi & Persentase & Ket. \\
\hline 1. & $X<(-1,0)$ & 10 & $14 \%$ & Rendah \\
\hline 2. & $(\mu-1,0 \alpha) \leq X<(\mu+1,0 \alpha)$ & 50 & $72 \%$ & Sedang \\
\hline 3. & $(\mu+1,0) \leq X$ & 10 & $14 \%$ & Tinggi \\
\hline & Jumlah & 34 & $100 \%$ & \\
\hline
\end{tabular}

Hasil analisis kategori di atas menunjukkan bahwa sebanyak 10 responden menilai tingkat kepemimpinan guru di sekolah masih rendah dengan porsentase sebesar $14 \%$, selanjutnya sebanyak 50 responden menilai tingkat kepemimpinan guru di sekolah berada pada kategori sedang dengan porsentase $72 \%$ dan 10 responden menilai tingkat kepemimpinan guru di sekolah berada pada kategori tinggi dengan porsentase 14\%. Dengan demikian dapat disimpulkan bahwa tingkat kepemimpinan guru berada pada kategori sedang.

\section{Gambaran Motivsi Belajar Peserta Didik di SMP Negeri 5 Enrekang}

Berdasarkan hasil penelitian yang telah dilakukan dengan 70 sampel dengan menggunakan angket motivasi belajar peserta didik dapat diperoleh data sebagai berikut: 
Tabel 3.

Statistik Hasil Analisis Motivasi Belajar Peserta Didik di SMP Negeri 5 Enrekang

\begin{tabular}{|c|c|}
\hline Statistik & Skor Statistik \\
\hline Jumlah Sampel & 70 \\
\hline Nilai Tertinggi & 40 \\
\hline Nilai Terendah & 30 \\
\hline Nilai Rata-Rata & 34,36 \\
\hline Satndar Deviasi & 2,335 \\
\hline
\end{tabular}

Tabel di atas menunjukkan memiliki nilai maksimum 40 dan nilai minimum 30. Sedangkan nilai rata-rata yang diperoleh sebesar 34,36 dan standar deviasi sebesar 2,335. Hasil anlisis deskriptif tersebut akan menggunakan data yang akan digambarkan dalam membuat kategorisasi motivasi belajar peserta didik. Adapun hasil kategorisasi dapat dilihat pada tabel berikut:

Tabel 4.

Distribusi Frekuensi Kategorisasi Motivasi Belajarar Peserta Didik di SMP Negeri 5 Enrekang

\begin{tabular}{|c|c|c|c|c|}
\hline No & Batas kategori & Frekuensi & Persentase & Ket. \\
\hline 1 & $X<(-1,0)$ & 7 & $10 \%$ & Rendah \\
\hline 2 & $(\mu-1,0 \alpha) \leq X<(\mu+1,0 \alpha)$ & 56 & $80 \%$ & Sedang \\
\hline 3 & $(\mu+1,0) \leq X$ & 7 & $10 \%$ & Tinggi \\
\hline & Jumlah & 70 & $100 \%$ & \\
\hline
\end{tabular}

Hasil analisis kategori di atas menunjukkan bahwa sebanyak 7 responden menilai tingkat motivasi belajar peserta didik masih rendah dengan porsentase sebesar $10 \%$, selanjutnya sebanyak 56 responden menilai tingkat motivasi belajar peserta didik berada pada kategori sedang dengan porsentase $80 \%$ dan 7 responden tingka motivasi belajar peserta didik berada pada kategori tinggi dengan porsentase $10 \%$. Dengan demikian dapat disimpulkan bahwa tingkat motivasi belajar peserta didik berada pada kategori sedang.

\section{Pengaruh Kepemimpinan Guru Terhadap Motivasi Belajar Peserta Didik di SMP Negeri 5 Enrekang}

Berikut merupakan tabel pendukung untuk melihat nilai signifikansi pengaruh kepemimpinan guru terhadap motivasi belajar peserta didik dapat dilihat pada tabel berikut: 
Tabel. 5.

Uji Signifikan Coefficientsa

\begin{tabular}{|cc|c|c|c|c|c|}
\hline \multirow{2}{*}{ Model } & \multicolumn{2}{|c|}{$\begin{array}{c}\text { Unstandardized } \\
\text { Coefficients }\end{array}$} & $\begin{array}{c}\text { Standardized } \\
\text { Coefficients }\end{array}$ & \multirow{2}{*}{$\mathrm{t}$} & \multirow{2}{*}{ Sig. } \\
\cline { 3 - 5 } & $\mathrm{B}$ & Std. Error & Beta & & \\
\hline \multirow{2}{*}{1} & (Constant) & 22.436 & 4.071 & & 5.511 & .000 \\
& Kep & .339 & .116 & .335 & 2.935 & .005 \\
\hline
\end{tabular}

Sumber : Data dari SPSS

Pada tabel coefisien pada kolom b constant a adalah 22,436 pada kolom b 0.339 sehingga persamaan regresinya dapat ditulis:

$\mathrm{Y}=\mathrm{a}+\mathrm{bx}$ atau $22.436+0.339 x$

Hipotesis statistik

$\mathrm{H}_{\mathrm{o}}: \beta=0$ (terdapat pengaruh yang signifikan)

$\mathrm{H}_{1}: \beta \neq 0$ (tidak terdapat pengaruh yang signifikan)

Uji signifikansi persamaan garis regresi diperoleh dari nilait hitung $=2,935$ dan

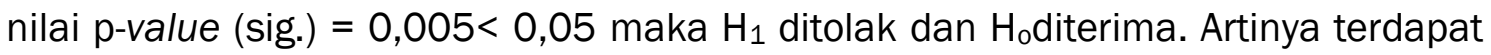
pengaruh antara kepemimpinan guru terhadap motivasi belajar peserta didik di SMP Negeri 5 Enrekang.

Tabel 6.

Koefisien Model Summary

\begin{tabular}{|c|c|c|c|c|c|}
\hline Model & $\mathrm{R}$ & $\mathrm{R}$ Square & $\begin{array}{c}\text { Adjusted R } \\
\text { Square }\end{array}$ & $\begin{array}{c}\text { Std. Error of } \\
\text { the Estimate }\end{array}$ & Durbin-Watson \\
\hline 1 & $.335^{\mathrm{a}}$ & .112 & .099 & 2.216 & 1.883 \\
\hline
\end{tabular}

Sumber: Data dari SPSS

Untuk melihat besarnya kontribusi variabel motivasi belajar terhadap kepemimpinan guru dapat dilihat pada nilai koefisien determinasi atau $R$ square pada tabel modelsummary sebesar 0,112 atau 11,2\% yang mengandung makna bahwa sebesar 0,112 atau 11,2\% variabel motivasi belajar dipengaruhi oleh variabel kepemimpinan guru.

\section{KESIMPULAN}

Berdasarkan hasil analisis data dan pembahasan yang telah dijelaskan sebelumnya, maka penulis dapat menarik kesimpulan sebagai berikut:

1. Berdasarkan hasil analisis deskripsi kepemimpinan guru pada tabel 4.3 memberikan gambaran bahwa kategori hasil angket kepemimpinan guru yaitu dalam kategori sedang. Nilai rata-rata kepemimpinan guru sebesar 34,36 dan ini menunjukan variabel kepemimpinan guru berada pada interval 24-37 pada tabel 4.4 sehingga disimpulkan berkategori sedang. Hal ini mengindikasikan bahwa kepemimpinan guru dengan indikator tersebut di atas cukup baik. 
2. Berdasarkan hasil analisis deskripsi motivasi belajar peserta didik pada tabel 4.3 memberikan gambaran kategori hasil angket tentang motivasi belajar yaitu dalam kategori sedang. Nilai rata-rata pada variabel motivasi belajar sebesar 35,17 dan ini menunjukan variabel motivasi belajar berada pada interval 24-37 pada tabel 4.5 sehingga disimpulkan berkategori sedang.Hal ini mengindikasikan bahwa motivasi belajar peserta didik dengan indikator tersebut diatas sudah cukup baik.

3. Berdasarkan hasil analisis statistik inferensial tentang pengaruh kepemimpinan guru dapat dilihat pada tabel 4.8 tentang kontribusi pengaruh kepemimpinan guru terhadap motivasi belajar peserta didik yang dilihat dari hasil penilaian 70 responden terhadap motivasi belajar peserta didik yang mempunyai $R$ square sebesar 0,112 atau pengaruh sebanyak $11,2 \% \mathrm{Hal}$ ini mengindikasikan bahwa pengaruh variabel $X$ terhadap variable $Y$ tersebut di atas sudah cukup baik.

\section{DAFTAR PUSTAKA}

A.M., Sardiman. Interaksi dan Motivasi Belajar-Mengajar. Jakarta: PT. Raja Grafindo Persada, 2008.

Abror, Rahman. Kepemimpinan Pendidikan Bagi Perbaikan dan Peningkatan Pengajaran. Yogyakarta: Nur Cahaya, 1984

Alwi, Marjani. Mengapa Anak Malas Belajar? Makassar: Alauddin University Press, 2012.

Arikunto, Suharsimi. Prosedur Penelitian Suatu Pendekatan Praktek, Jakarta: Rineka Cipta, 2002.

Azisah, Siti. Guru dan Pengembangan Kurikulum Berkarakter Implementasi pada Tingkat Satuan Pendidikan. (Cet. I: Jakarta: Alauddin University Press, 2014).

Azwar, Saifuddin. Metode Penelitian. Yogyakarta: Pustaka Pelajar: 2007.

Buchari, Alma. Guru Profesional. Bandung: Alfabeta, 2014

Departemen Agama RI. Al-Qur'an dan Terjemahnya, Semarang: PT. KaryaToha Putra Semarang, 2002

Departemen Agama RI. Himpunan Peraturan Perundang-undangan Sistem Pendidikan Nasional. Jakarta: Binbaga Islam, 1991/1992

Djamarah, Syaiful Bahri. Psikologi Belajar. Jakarta: Rineka Cipta, 2008.

Hadi, Sutrisno. Metodologi Research Jilid 1, Yogyakarta: Andi Offset, 1991.

Hasbullah. Dasar-dasar IImu Pendidikan, Jakarta: Edisis Revisi PT. Raja Grafindo Persada, 2005

Kartono, Kartini. Pemimpin dan Kepemimpinan, Jakarta: PT. Grafindo, 1992.

Karwati, Euis \& Donni Juni Priansa. Manajemen Kelas. Bandung: ALFABETA, 2014. 
Masnur, Muslich. KTSP, Panduan bagi Guru, Kepala Sekolah dan Pengawas Sekolah. Jakarta: Bumi Aksara, 2007

Mudjiono dan Dimyati. Belajar dan Pembelajaran. Jakarta: Rineka Cipta, 2006

Mulyasa, E. Menjadi Guru Profesional, Bandung: PT. Rosda Karya, 2006.

Muzakkir. Microteaching Teori dan Aplikasinya, (Makassar: Alauddin University Press, 2012).

Nashar. Peranan motivasi dan Kemampuan Awal dalam Kegiatan Pembelajaran, Jakarta: Delia Press, 2004

Ormrod, Jeanne Ellis. Psikologi Pendidikan, Jakarta: Penerbit Erlangga, 2009.

Rahim, Abdul, Sistem Pemberian Balikan dan Motivasi Berprestasi. Makassar: Alauddin University Press, 2012

Rivai, Veithzal \& Sylviana Murni. Education Management Analisis Teori dan Praktik, Jakarta: PT Raja Grafindo Persada, 2012.

Siagian, Sondang P. Teori dan Praktek Kepemimpinan, Jakarta: Bina Aksara, 1988.

Slameto. Belajar dan Faktor-faktor yang Mempengaruhinya. Jakarta: Rineka Cipta, 2010.

Sugiono. Metode Penelitian Pendidikan: Pendekatan Kuantitatif, Kualitatif dan $R \& D$. Bandung: Alfabeta, 2015.

Supardi. Kinerja guru. Cet. II: Jakarta: Rajawali Pers, 2014.

Surya, Mohamad. Psikologi Guru, Konsep dan Aplikasi Dari Guru untuk Guru. Bandung: Alfabeta,2014

Sutrisno, Edy. Manajemen Sumber Daya Manusia. Jakarta: Kencana Prenada Media Group, 2009.

Undang-Undang Republik Indonesia Nomor 20 Tahun 2003 tentang Sistem Pendidikan Nasional, (Jakarta: BP. Cipta Jaya, 2003).

Undang-Undang Republik Indonesia Nomor 20 Tahun 2003 tentang Sistem Pendidikan Nasional.

Widoyono, Eko Putro. Teknik Penyusunan Instrumen Penelitian. Yogyakarta: Pustaka Pelajar, 2014.

Yamin, Martinis. Kiat Pembelajaran Siswa, Jakarta: Gaung Persada Press Jakarta, 2007. 